\title{
Hydrothermal influence on rock weathering in the Kirishima volcanic complex
}

GIBRAN ROMERO MUJALLI ${ }^{1,2}$, JENS HARTMANN ${ }^{3}$ TAKAHIRO HOSONO ${ }^{4}$, KIYOSHI IDE ${ }^{5}$, THORBEN AMANN $^{1}$ AND PASCALE LOUVAT $^{6}$

${ }^{1}$ University of Hamburg

${ }^{2}$ Universidad Central de Venezuela

${ }^{3}$ Universität Hamburg

${ }^{4}$ Kumamoto University

${ }^{5}$ Shibaura Institute of Technology

${ }^{6}$ Université de Paris-Institut de physique du globe de ParisCNRS, UMR 7154

Presenting Author: gibran.mujalli@gmail.com

The global weathering flux of volcanic areas is often scaled with runoff and temperature. However, it was identified that alkalinity fluxes decrease with the age of the basaltic rocks drained. A combination of hydrothermal activity and production of fresh rocks through volcanic eruptions seems to be most likely governing this relationship. In addition, weathering rate equations, from thermodynamics, can be scaled with the reaction time, residence time, the dimension (volume or length) and the temperature of the system. In this study, the chemistry of rivers and springs from the Kirishima volcanic complex (Japan) is analyzed. By combining spring water residence times with multiisotope composition of $\delta^{13} \mathrm{C}_{\mathrm{DIC}}, \delta^{34} \mathrm{~S}_{\text {sulphate }}, \delta^{18} \mathrm{O}_{\text {sulphate }}, \delta^{18} \mathrm{O}_{\text {water }}$, $\delta^{2} \mathrm{H}_{\text {water }}$ and trace element concentrations, the hydrothermal component can be distinguished. We also compared the apparent chemical kinetic constant of primary minerals in the volcanic rocks with those measured in other studies to determining transport or equilibrium controls on weathering in this system. The magmatic $\mathrm{CO}_{2}$ and $\mathrm{SO}_{2}$ are responsible for a significant proportion of the enhanced weathering if compared to inactive volcanic systems. In general, the apparent weathering rate in the Kirishima volcanic complex seems to be transport controlled and can be scaled up with the residence time of the spring waters. Given the complexity of hydrothermal processes and the admixing of different fluids with varying fluid-rock interactions, we also highlight the importance of regional studies in volcanic settings to simplifying the investigation of weathering pathways. In this study case, it seems that a first order chemical kinetic equation of Kirishima's primary minerals (augite, hypersthene and plagioclase) may describe the system. 
